\title{
EDITORIAL
}

\section{Immunogenetics and schizophrenia ${ }^{1}$}

There is overwhelming evidence for a major contribution of genetic elements to the aetiology of schizophrenia (Slater \& Cowie, 1971), but the principal problems remain; what is the nature of the hereditary contribution, and what is the path by which genetic information is translated into a frank behavioural disorder?

The genetic evidence comes not only from the well-known family studies (Ødegaard, 1963 ; Elsässer, 1952; Scnulz, 1932; Hallgren \& Sjögren, 1959; Kay et al. 1975) and twin studies (Luxenburger, 1930; Essen-Möller, 1941; Kallmann, 1946; Slater, 1953; Tienari, 1968; Kringlen, 1968; Fischer et al. 1969; Gottesman \& Shields, 1972), but also from the convincing cross-fostering and adoption studies (Heston, 1966; Kety et al. 1968; Mednick et al. 1974). From the latter, it seems clear that children with an affected biological parent have the same elevated chance of becoming ill, irrespective of whether they are reared by the natural parent or an adoptive or foster parent. That adoptive or foster homes are not themselves 'schizophrenogenic' is confirmed by the findings (Wender $e t$ al. 1971, 1974; Karlsson, 1974) that there is no increased incidence of schizophrenia in adopting parents or their other adopted children. In summary,

the evidence indicates that the psychosis risk is already fixed at birth, and since the rates are the same in offspring in schizophrenic fathers and mothers one may conclude that the risk is actually set at the time of conception. The family environment seems to be excluded as a significant cause of schizophrenic illness. No family-connected factors have been identified that are not fully accounted for by the hereditary contribution (Karlsson, 1974).

The fact that the genetic element is not simple, however, is indicated by the discordance, varying in magnitude from study to study, found in identical twins. Twin studies are notoriously difficult to interpret except where they form part of fuller family analyses; the concordance in dizygotic twins depends on the population frequency of the disease as well as on its severity (Childs, 1976) and inheritance and, where heritability is not absolute, a concordance rate in identical twins may be quite low. However, there are data (Kety, 1978) suggesting that the children of an unaffected discordant twin do develop the illness in the expected proportions. Again, some life-event studies (Brown \& Birley, 1968; Uhlenhuth \& Paykel, 1972; Eisler \& Polak, 1971) purport to demonstrate that the stress of adverse experiences can initiate the illness (psychogenic psychosis). However, other similar studies do not (Morrison et al. 1968; Murphy et al. 1962; Hudgens et al. 1973). Moreover, closer analysis of some of the positive studies shows serious methodological weaknesses; for example, one showed an increase in antecedent life events only by excluding the classical insidious onset cases characteristic of the nuclear condition (Brown \& Birley, 1968). This does not mean, of course, that adverse life events are unimportant in precipitating relapse; they are, indeed, crucial in destabilizing (Leff et al. 1973) the contained patient. Certainly a role for physical stress factors in the pathogenesis cannot at present be ruled out, as for example in puerperal schizophrenia (Hays, 1978), while likewise ingestion of lysergic acid diethylamide may produce the same effect in a predisposed subject (Anastasopoulos \& Photiades, 1962) or at least accelerate the onset of the disorder.

In the light of such evidence for both genetic and environmental elements in the aetiology, several inheritance models of schizophrenia have been proffered but remain unverified. There is good, but not yet conclusive, evidence for the monogenic (dominant) thesis (Slater, 1972). Thus Heston's (1970) work and data from Karlsson (1973) argue cogently for the presence of a dominant principal

1 Address for correspondence: Professor D. F. Roberts, Department of Human Genetics, The University, 19 Claremont Place, Newcastle upon Tyne NE2 4AA. 
gene, while Kety (1978), in his family study of half-sibs, found a very high incidence (50\% risk) in half-sibs where the common parent was schizophrenic. But the argument for a polygenic mode of inheritance, which allows for the combined effect of environmental and hereditary elements, is just as acceptable, and suggests that the genetic contribution predominates, with a heritability of upwards of $60 \%$ (Gottesman \& Shields, 1968). This dispute, however, is of secondary importance to discovery of the mechanism by which the genetic error is implemented.

\section{IMMUNOGENETICS}

In the last decade there has been a remarkable development of immunogenetics as applied to man. Genetic factors have been shown to be implicated at a number of points in both the humoral and cellular immune responses. In the humoral response, following the definition of the molecular structure of the immunoglobulins, the number of genes controlling the regions of their several chains has been indicated, and also how they act (Milstein \& Munro, 1973). The marker allotypes, the Gm, Inv and Am groups, have been shown to be due to single amino acid substitutions which are point mutations in the sequences coding for the chains of immunoglobulins (Grubb, 1970). Besides these qualitative differences, some genetic influence on the level of immunoglobulins in apparently healthy individuals has been demonstrated (Billewicz et al. 1974), and though many deficiencies are nongenetic, the inherited bases of several, especially of $\operatorname{IgA}$ and $\operatorname{IgM}$, have been established (Grund. bacher, $1972 a, b$; Kelch et al. 1971; Waldmann et al. 1976; Tomkin et al. 1971). In the complement system, similarly, there are polymorphisms - different alleles at the same locus producing slightly different substances - in each of the components of complement except $\mathrm{C} 5$, and again there are genes responsible for deficiency of specific components (Day et al. 1972; Klemperer et al. 1966; Polley, 1968; Leddy et al. 1974; Boyer et al. 1975). The existence of genetically controlled circulating antibodies has long been known.

At the cellular level, blood-group antigens on the red cells were the earliest to be discovered (Landsteiner, 1901). Lymphocytes have provided a particularly vigorous development, notably in the exploration of the human chromosome major histocompatibility region (Bodmer et al. 1978; WHO, 1975), the identification of a large number of alleles at the loci controlling the HLA-A and B antigens, and rather smaller numbers at the HLA-C and D loci. The differentiation of B and T cells by rosetting and immunofluorescence has led to the identification of $B$ cell types and $T$ cell types, again under genetic control, and indeed another major polymorphic system of cell surface antigens (reminiscent of mouse Ia antigens) has been established in man.

These developments have had a profound effect in various fields of somatic medicine. Yet the application of immunogenetic concepts to schizophrenia appears to have lagged somewhat, despite the facts that an auto-immune hypothesis of schizophrenia was put forward as long ago as 1967 (Heath \& Krupp, 1967) and that there is good evidence for a weak association with the red cell surface antigens. For schizophrenia, there have been some 40 studies of ABO associations, covering over 12000 patients (Mourant et al. 1978). Though the results differ among themselves, there is a strong suggestion of an elevated incidence of bloodgroup B. Schizophrenia is the only one of the psychoses to show such an association, and of the several classical genetic markers examined in schizophrenia only the B bloodgroup demonstrates an association. It is possible that further exploration in an immunogenetic context would provide the clue for the next stage of advance in the understanding of the disorder.

One area of immunogenetics in which there has been recent interest in schizophrenia is the HLA association. The HLA (human leukocyte antigen) histocompatibility system is controlled by several loci situated close together on the short arm of human chrcmosome 6 . There is great polymorphism in this system, in that at each locus there are many different alleles available, so that millions of distinguishable antigenic configurations can be derived - a veritable demonstration of the individuality of the human genotype. Other genes also are thought to occur in this region analogous to the immune response (Ir) genes that are known in animals. The demonstration of associations between histocompatibility antigens and disease has been particularly useful. First, it has caused recon- 
sideration of aetiologies, has demonstrated relationships between a number of diseases, and has shown what a wide range of disorders stems from immunopathology. Secondly, it has suggested mechanisms by which the disorders are brought about. Thirdly, associations, where close, may aid in diagnosis, as with B27 in ankylosing spondylitis. None of the disease associations is absolute. Even in the case of ankylosing spondylitis, the disorder with the strongest HLA association, only a minority of B27 positive persons actually develop it; this genetic factor alone is thus not a sufficient condition for the production of the disorder, and obviously some trigger is necessary to convert a predisposition to a manifestation of disease.

There have now been some 20 studies of HLA types in schizophrenia. There is little concordance in results, either between studies or between subgroups of patients within a study. Overall, the most consistent increase in frequency appears for antigens A28, Cw4, B18, B9 and B5, though each of these is visible in only a minority of studies. Several groups of workers have tried to delineate the paranoid and hebephrenic subtypes - a dubious exercise - and here increased frequencies of $\mathrm{Al}$ in hebephrenic and A9 in paranoid are the most consistent; of critical relevance, the diagnostic criteria of these subtypes differ in the different studies. Practically all such studies refer to analyses of patient populations, and while they are useful in providing pointers, the interpretation of their results is often ambivalent. Sample size is all too frequently small, so that an apparent association may be a sampling artefact, even assuming that techniques are reliable. If an antigen association is validated, it may indicate that the antigen itself contributes to the aetiology, perhaps because of its antigenic similarity to some virus or as part of a polygenic system making for liability to the disorder. One major criticism lies in the diagnostic criteria. Only when the patients for inclusion in such studies are accepted on the basis of rigorous criteria would it be meaningful to attempt comparison between series. In this respect, it is interesting that the elevation of $\mathrm{Al}$ was found in one study in 57 patients with Schneiderian first-rank criteria (McGuffin et al. 1978). Another criticism is the absence of family studies, for these supply essential information that population surveys cannot. They are crucial to the establishment of the correctness of the interpretations suggested by population studies. Only they can elucidate the relationship of the HLA (or indeed any other) genotype to the disease-conferring genes: whether it is the HLA antigen itself, whether it is some other linked gene, whether the association represents a multifactorial or monogenic inheritance and, if the former, whether it is the antigen itself that is involved or whether it reflects the susceptibility of particular families with their particular genetic constitution quite independent of the antigen. Family studies are at present in progress in at least two centres in Britain (Newcastle upon Tyne and London).

Future studies of HLA in schizophrenia should, therefore, involve (a) larger numbers of propositi so that pooling of data from different series from different localities becomes unnecessary, and subdivision by clinical or other details is possible; $(b)$ the use of criteria for clinical diagnosis that are as clear and as standardized as possible; $(c)$ a rigorous statistical approach, and the incorporation of actuarial data (which may well be more predictive of the outcome than clinical symptoms) rather than the more subjective attempts at categorization; $(d)$ the incorporation of family studies.

\section{MECHANISMS}

For an immunogenetic hypothesis to be acceptable, there requires to be a mechanism, either some identifiable defect in the immune system or some substance evoking the specific immune response. For the first there is relatively little evidence, and more could be done following up by modern techniques some of the early suggestions (Heath \& Krupp, 1967). The presence of abnormal leukocytes has been claimed (Fessel \& Hirata-Hibi, 1963); so has a reduction in the number of DNAsynthesizing lymphocytes (Babayan et al. 1976), while elevation of autoantibodies (Ismailov, 1972), of globulin plasma factor, of serum IgA, and of CSF Ig or measles antibody (Fuller-Torrey, 1978) are reported, though some at least of these findings may reflect the effect of extrinsic factors. The second implies some structural, biochemical, or inflicted change in patients to which their immune system can respond, acting perhaps against imbalance or breakdown products, or an infecting organism. 
There is a veritable mountain of data - neurological (Quotkin et al. 1976; Larsen, 1964; Hertzig \& Birch, 1966), psychophysiological (Tucker et al. 1975; Myers et al. 1973; Ornitz, 1970; Saarma, 1974; Cowen, 1973; Shagass et al. 1974; Brezinova \& Kendell, 1977; Gruzelier \& Venables, 1972), encephalographic (Davis, 1942; Jasper et al. 1939; Sem-Jacobsen et al. 1955; Kennard \& Levy, 1952), anatomical (Weinberger et al. 1979; Jellinek, 1976; Johnstone et al. 1978; Marsden, 1976), biochemical (Perry et al. 1979; Bird et al. 1977; Arreevi et al. 1979) - suggesting an organic basis. Kraepelin himself held that brain pathology would one day prove to be the key, though he cited (wrongly) Alzheimer morphology as characteristic. There is little doubt that subtle yet severe brain dysfunction, involving defective cognitive filtering or disturbed neurochemical processes, is fundamental. The confirmation of an HLA association would direct attention to the most promising paths to follow in exploring that mountain.

Functionally, the HLA gene complex controls both the inner and outer structures of cellular membranes via their topochemistry. All nervous system functions are very dependent on the properties of cellular membrane, and many of the biological investigations of schizophrenia have been concerned with the pathology of such structures. Thus disturbances in permeability (e.g. for neurotransmitters), receptor properties (e.g. toxins, viruses, drugs), and antigenicity conditions (e.g. for auto-immunity development) have all been suggested.

In support of the biochemical involvement in schizophrenia, acting via neurohumoral function, there is the exacerbation of symptoms in patients, and their induction in normals, by drugs such as the amphetamines (Kornetsky, 1976), probably associated with dopaminergic activity, and the reduction of symptoms by neuroleptic drugs (Crow \& Gillbe, 1974). There is evidence from studies of post-mortem material and of dopamine turnover, not that dopamine neurones are overactive in schizophrenia, but that the number of dopamine receptors is increased in the brain of the majority of schizophrenic patients (Owen et al. 1978). While such an increase, or the capacity for it, may be intrinsic, there may well be an element of induction, presumably over a period, suggesting a triggering effect of, say, a slow-acting virus. For this there is some recent evidence (Tyrrell et al. 1979; Crow et al. 1979) and this would conceivably be one mechanism for an HLA association; for example, if the configuration of the virus resembles that of an HLA antigen, it would not be recognized as foreign by those carrying that antigen ; or the product of the locus might affect some stage in the viral replication cycle, or determine an abnormal response to an otherwise common virus.

A direct attack on humoral and cellular immunity in schizophrenia in Russia embraces the two mechanisms (Vartanian et al. 1978; Liedeman \& Prilipko, 1978). One area of enquiry concerns the identification of brain tissue antigens to which antibodies are detectable in sera from schizophrenic patients. These occur at an elevated frequency over that from normals, and appear to be directed against alpha ${ }^{2}$ glycoprotein. Another area concerns the functional activity of lymphocytes of schizophrenic patients. Response to phytohaemaglutanin and concanavlin $A$ is reduced, there is an increased proportion of $B$ lymphocytes and reduction of active $T$ lymphocytes, and it appears that the serum from most $(81 \%)$ schizophrenic patients contains substances which reduce the number of DNA synthesizing cells in the mitogen-stimulated culture. It is unlikely that the total number of $T$ lymphocytes is reduced, but instead that there exists a population of silent $T$ lymphocytes in schizophrenic patients, that is, the cells do not respond to T mitogen. Antibodies to T lymphocytes appear to be one of the substances which produce such an inhibiting effect, and it seems that the same holds for antibodies to brain antigens since the human brain possesses antigenic determinants very similar to those of human thymocytes. Indeed, antithymic activity in the serum of schizophrenic patients tends to be higher than in normals. It is, moreover, intermediate in relatives of schizophrenic patients though the distributions overlap, and this suggestion of some genetic control is supported by the significance of the correlation of the quantitative levels among biological relatives and its absence between spouses, and by the different frequencies of antibodies against brain tissue in relatives of patients with and without such antibodies. Unfortunately, this index is not specific to schizophrenics, for similar levels are found in manic depressives and patients with thyrotoxic goitre.

These and other studies, if confirmed, would suggest that there exist factors in the serum of schizophrenic patients that somehow change the physiological and functional state of the peripheral blood 
lymphocytes, and that there is an appreciable genetic element governing the presence of such factors. A logical next step would be to isolate individual lymphocyte subpopulations, to discover which of them may be producing suppressive factors.

The idea that schizophrenia may be an immunogenetic problem is a sapling with many branches. If it is still too early to decide which should be pruned out and which nurtured to provide the mature tree of understanding, the young plant itself appears vigorous.

\section{F. ROBERTS AND H. G. KINNELL}

\section{REFERENCES}

Anastasopoulos, G. \& Photiades, H. (1962). Effect of LSD-25 on relatives of schizophrenic patients. Journal of Mental Science 108, 95-98.

Arreevi, A., Mackay, A. V., Iversen, L. L. \& Spokes, E. G. (1979). Reduction of angiotensin-converting enzyme in substantia nigra in early onset schizophrenia. New England Journal of Medicine 300, 502-503.

Babayan, N. G., Sekoyan, R. V. \& Prilipko, L. L. (1976). The effect of serum of schizophrenic patients and of normal donors on the NA synthesis of lymphocytes. Byulleten eksperimentalnoi biologii $i$ meditsiny 81 (4), 430-432.

Billewicz, W. Z., McGregor, I. A., Roberts, D. F., Rowe, D. S. \& Wilson, R. J. M. (1974). Family studies in immunoglobulin levels. Clinical and Experimental Immunology 16, 13-22.

Bird, E. D., Spokes, E. G., Barnes, J., Mackay, A. V., Iversen, L. L. \& Shepherd, M. (1977). Brain norepinephrine and dopamine in schizophrenia. Lancet ii, 1157-1159.

Bodmer, W. F., Bodmer, J. G., Batchelor, J. R., Festenstein, H. \& Morris, P. (eds.) (1978). Histocompatibility Testing 1977. Munksgaard: Copenhagen.

Boyer, J. T., Gall, E. P., Norman, M. E., Nilsson, U. R. \& Zimmerman, T. S. (1975). Hereditary deficiency of the seventh component of complement. Journal of Clinical Investigation 56, 905-913.

Brezinova, V. \& Kendell, R. E. (1977). Smooth pursuit eye movements of schizophrenics and normal people under stress. British Journal of Psychiatry 130, 59-63.

Brown, G. W. \& Birley, J. L. T. (1968). Crisis and life changes and the onset of schizophrenia. Journal of Health and Social Behaviour 9, 203-214.

Childs, B. (1976). Human behavioural genetics. In Aspects of Genetics in Paediatrics (ed. D. Barltrop), pp. 45-53. Fellowship of Postgraduate Medicine: London.

Cowen, M. A. (1973). Electrophysiological phenomena associated with the S-protein system in normal and schizophrenic subjects. Biological Psychiatry 7, 113-127.

Crow, T. J. \& Gillbe, C. (1974). Brain dopamine and behaviour. A critical analysis of the relationship between dopamine antagonism and therapeutic efficacy of neuroleptic drugs. Journal of Psychiarric Research 11, 163-172.

Crow, T. J., Ferrier, I. N. \& Johnstone, E. C. (1979). Characteristics of patients with schizophrenia or neurological disorder and virus-like agent in cerebrospinal fluid. Lancet i, 842-844.

Davis, P. A. (1942). Comparative study of the EEGs of schizophrenic and manic depressive patients. American Journal of Psychiatry 99, 210-217.

Day, N. K., Geiger, H., Stroud, R., de Bracco, M., Mancado, B.,Windhorst, D. B. \& Good, R. A. (1972). CIr deficiency: an inborn error associated with cutaneous and renal disease. Journal of Clinical Investigation 51, 1102-1108.

Eisler, M. \& Polak, P. R. (1971). Social stress and psychiatric disorder. Journal of Nervous and Mental Disease 153, 227233.

Elsüsser, G. (1952). Die Nachkommen Geisteskranker Eltempaare. Thieme: Stuttgart.
Essen-Möller, E. (1941). Psychiatrische Untersuchungen an einer Serie von Zwillingen. Acta psychiatrica scandinavica Suppl. 23.

Fessel, W. J. \& Hirata-Hibi, M. (1963). Abnormal leukocytes in schizophrenia. Archives of General Psychiatry 9, 601613.

Fischer, M., Harvald, B. \& Hauge, M. (1969). A Danish twin study of schizophrenia. British Journal of Psychiarry 115, 981-990.

Fuller-Torrey, E. (1978). Immunoglobulins and viral antibodies in psychiatric patients. British Journal of Psychiatry 132. 342-348.

Gottesman, I. I. \& Shields, J. (1968). In pursuit of the schizophrenic genotype. In Progress in Human Behaviour Genetics (ed. S. G. Vandenberg), pp. 67-103. Johns Hopkins Press: Baltimore.

Gottesman, I. I. \& Shields, J. (1972). Schizophrenia and Genetics: a Twin Study Vantage Point. Academic Press: New York.

Grubb, R. (1970). The Genetic Markers of Human Immunoglobulins. Chapman \& Hall: London.

Grundbacher, F. J. $(1972 a)$. Genetic aspects of selective immunoglobulin A deficiency. Journal of Medical Genetics 9, 344-347.

Grundbacher, F. J. (1972b). Human X chromosome carries quantitative genes for immunoglobulin M. Science 178, 311-312.

Gruzelier, J. H. \& Venables, P. H. (1972). Skin conductance and orienting activity in a heterogeneous sample of schizophrenics: possible evidence of limbic dysfunction. Journal of Nervous and Mental Disease 155, 277-287.

Hallgren, B. \& Sjögren, T. (1959). A clinical and geneticostatistical study of schizophrenia and low-grade mental deficiency in a large Swedish rural population. Acta psychiatrica scandinavica Suppl. 140.

Hays, P. (1978). Taxonomic map of the schizophrenics, with special reference to puerperal psychosis. British Medical Journal ii, 755-757.

Heath, R. G. \& Krupp, I. M. (1967). Schizophrenia as an immunologic disorder. Archives of General Psychiarry 16, $1-33$.

Hertzig, M. E. \& Birch, H. G. (1966). Neurologic organisation in psychiatrically disturbed adolescent girls. Archives of General Psychiatry 15, 590-598.

Heston, L. L. (1966). Psychiatric disorders in foster-home reared children of schizophrenic mothers. British Journal of Psychiatry 112, 819-825.

Heston, L. L. (1970). The genetics of schizophrenia and schizoid disease. Science 167, 249-256.

Hudgens, R. W., Morrison, J. R. \& Barchka, R. G. (1973). Personal catastrophe and depression: a consideration of the subject with respect to medically-ill adolescents, and a requiem for retrospective 'life event' studies. Presented at the Conference on Stressful Life Events at City University of New York, 5 June 1.073.

Ismailov, T. I. (1972). A study of autoantibodies to DNA in schizophrenics and other neuropsychiatric disorders. Zhurnal neuropatologii i psikhiatrii imeni S.S. Korsakova $72(8), 1188-1191$. 
Jasper, H. H., Fitzpatrick, C. P. \& Solomon, P. (1939). Analogues and opposites in schizophrenia and epilepsy. American Journal of Psychiatry 95, 835-851.

Jellinek, E. H. (1976). Cerebral atrophy and cognitive impairment in chronic schizophrenia. Lancet ii, 12021203.

Johnstone, E. C., Crow, T. J., Frith, C. D., Stevens, M., Kreel, L. \& Husband, J. A. (1978). The dementia of dementia praecox. Acta psychiatrica scandinavica 57, $305-324$.

Kallmann, F. J. (1938). The Genetics of Schizophrenia. Augustin: New York.

Kallmann, F. J. (1946). The genetic theory of schizophrenia: an analysis of 691 schizophrenic twin index families. American Journal of Psychiatry 103, 309-322.

Karlsson, J. L. (1973). An Icelandic family study of schizophrenia. Brinish Journal of Psychiatry 123, 549-554.

Karlsson, J. L. (1974). Inheritance of schizophrenia. Acta psychiatrica scandinavica Suppl. 247, p. 103.

Kay, D. W. K., Roth, M. \& Atkinson, M. W. (1975). Genetic hypotheses and environmental factors in the light of psychiatric morbidity in the families of schizophrenics. British Journal of Psychiatry 127, 109-1 18.

Kennard, M. A. \& Levy, S. (1952). The meaning of the abnormal EEG in schizophrenia. Journal of Nervous and Mental Disease 116, 413-423.

Kelch, R. P., Franklin, M. \& Schmickel, R. D. (1971). Group $\mathrm{D}$ deletion syndrome. Journal of Medical Genetics 8, 341345.

Kety, S. (1978). The syndrome of schizophrenia. The Maudsley Lecture, 17 November 1978, given to the Royal College of Psychiatrists, London. Reprinted (1980) in British Journal of Pschiatry 136, 421-436.

Kety, S. S., Rosenthal, D., Wender, P. \& Schulsinger, F. (1968). The types and prevalence of mental illness in the biological and adoptive families of adopted schizophrenics. In The Transmission of Schizophrenia (ed. D. Rosenthal and S. S. Kety). Pergamon Press: Oxford.

Klemperer, M. R., Woodworth, H. C., Rosen, F. S. \& Austen, K. F. (1966). Hereditary deficiency of 2 nd component of complement in man. Journal of Clinical Investigation 45, 880-890.

Kornetsky, C. (1976). Hyporesponsivity of chronic schizophrenic patients to dextroamphetamine. Archives of General Psychiarry 33, 1425-1428.

Kringlen, E. (1968). An epidemiological-clinical twin study on schizophrenia. In The Transmission of Schizophrenia (ed. D. Rosenthal and S. S. Kety). Oxford University Press: London.

Landsteiner, K. (1901). Über Agglutinationserscheinungen normalen menschlichen Blutes. Wiener Klinische Wochenschrift 14, 1132-1134.

Larsen, V. L. (1964). Physical characteristics of disturbed adolescents. Archives of General Psychiatry 10, 55-88.

Leddy, J. P., Frank, M. M., Gaither, T., Baum, J. \& Klemperer, M. R. (1974). Hereditary deficiency of the 6th component of complement in man, I. Journal of Clinical Investigation 53, 544-553.

Leff, J. P., Hirsch, S. R., Gaind, R., Rohde, P. D. \& Stevens, B. C. (1973). Life events and maintenance therapy in schizophrenic relapse. British Journal of Psychiatry 123, 659-660.

Liedeman, R. R. \& Prilipko, L. L. (1978). The behaviour of $T$ lymphocytes in schizophrenia. Birth Defects: Original Arricle Series, 14, 365-377.

Luxenburger, H. (1930). Heredität und Familientypus der Zwangsneurotiker. Archiv für Psychiatrie 91, 590-594.

Marsden, C. D. (1976). Cerebral atrophy and cognitive impairment in chronic schizophrenia. Lancet ii, 1079.

McGuffin, P., Farmer, A. E. \& Rajah, S. M. (1978). Histo. compatibility antigens and schizophrenia. British Journal of Psychiatry 132, 149-151.

Mednick, S. A., Schulsinger, F., Higgins, J. \& Bell, B. (1974). Genetics, Environment and Psychopathology. NorthHolland: Amsterdam.

Milstein, C. \& Munro, A. J. (1973). Genetics of immunoglobulins and of the immune response. In Defence and Recognition (ed. R. R. Porter), pp. 199-228. Butterworth: London.

Morrison, J. R., Hudgens, R. W. \& Barchka, R. G. (1968). Life events and psychiatric illness. British Journal of Psychiatry 114, 423-432.

Mourant, A. E., Kopec, A. C. \& Domaniewska-Sobczak, K. (1978). Blood Groups and Diseases. Oxford University Press: London.

Murphy, G. E., Robins, E., Kulin, N. O. \& Christensen, R. F. (1962). Stress, sickness and psychiatric disorder in a 'normal' population: a study of 101 young women. Journal of Nervous and Mental Disease 134, 228-236.

Myers, S., Caldwell, D. \& Purcell, G. (1973). Vestibular dysfunction in schizophrenia. Biological Psychiatry 7, 255-261.

Ødegaard, $\varnothing$. (1963). The psychiatric disease entities in the light of a genetic investigation. Acta psychiatrica scandinavica 39, Suppl. 169, 94-104.

Ornitz, E. M. (1970). Vestibular dysfunction in schizophrenia and childhood autism. Comprehensive Psychiarry 11, 159173.

Owen, F., Cross, A. J., Crow, T. J., Longden, A., Poulter, M. \& Riley, G. J. (1978). Increased dopamine-receptor sensitivity in schizophrenia. Lancet ii, 223-225.

Perry, T. L., Buchanan, J., Kish, S. J. \& Hansen, S. (1979). Gamma-aminobutyric-acid deficiency in brains of schizophrenic patients. Lancet i, 237-239.

Polley, M. J. (1968). Inherited C'3 deficiency in man. Science 161, 1149-1151.

Quotkin, F., Rifkin, A. \& Klein, D. F. (1976). Neurologic soft signs in schizophrenia and character disorders. Archives of General Psychiatry 33, 845-853.

Saarma, J. (1974). Autonomic component of the orienting reflex in schizophrenics. Biological Psychiatry 9, 55-60.

Schulz, B. (1932). Zur Erb pathologie der Schizophrenie. Zeitschrift fïr die gesamte Neurologie und Psychiatrie 143, 175-293.

Sem-Jacobsen, C. W., Petersen, M. C., Lazarte, J. A., Dodge, H. W. Jr \& Holman, C. B. (1955). Intracerebral electrographic recordings from psychotic patients during hallucinations and agitation. American Journal of Psychiatry 112, 278-288.

Shagass, C., Amadeo, M. \& Overton, D. A. (1974). Eyetracking performance in psychiatric patients. Biological Psychiatry 9, 245-260.

Slater, E. (1953). Psychotic and Neurotic Illnesses in Twins. MRC Special Report Series no. 278. HMSO: London.

Slater, E. (1972). The case for a major partially dominant gene, In Genetic Factors in Schizophrenia (ed. A. Sorsby and N. E. Morton), pp. 173-180. C. C. Thomas: Springfield, Ill.

Slater, E. \& Cowie, V. (1971). The Genetics of Mental Disorders. Oxford University Press: London.

Tienari, P. (1968). Schizophrenia in monozygotic male twins. In The Transmission of Schizophrenia (ed. D. Rosenthal and S. S. Kety). Oxford University Press: London.

Tomkin, G. H., Mawhinney, M. \& Nevin, N. C. (1971). Isolated absence of $\mathrm{IgA}$ with autosomal dominant inheritance. Lancet ii, 124-125.

Tucker, G. J., Campion, E. W. \& Silberfarb, P. M. (1975). Sensorimotor functions and cognitive disturbance in psychiatric patients. American Journal of Psychiatry 132, $17-21$. 
Tyrrell, D. A. J., Parry, R. P., Crow, T. J., Johnstone, E. \& Ferrier, I. N. (1979). Possible virus in schizophrenia and some neurological disorders. Lancer i, 839-841.

Uhlenhuth, E. H. \& Paykel, E. S. (1972). Symptom intensity and life events. Archives of General Psychiatry 28, 473-477.

Vartanian, M. E., Kolyaskina, G. I., Lozovsky, D. V., Burbaeva, G. S. \& Ignatov, S. A. (1978). Aspects of humoral and cellular immunity in schizophrenia. In Neurochemical and Immunologic Components in Schizophrenia (ed. D. Bergsma and A. L. Goldstein), pp. 339-364. Alan Liss: New York.

Waldmann, T. A., Broder, S., Krakauer, R., Durm, M., Meade, B. \& Goldman, C. (1976). Defects in immunoglobulin $A$ secretion and in immunoglobulin A specific suppressor cells in patients with isolated immunoglobulin A deficiency. Clinical Research 24, 483A.
Weinberger, D. R., Torrey, E. F. \& Wyatt, R. J. (1979). Cerebellar atrophy in chronic schizophrenia. Lancet $\mathrm{i}$, 718-719.

Wender, P. H., Rosenthal, D., Zahn, T. P. \& Kety, S. S. (1971). The psychiatric adjustment of the adopting parents of schizophrenics. American Journal of Psychiatry 127, 1013-1018.

Wender, P. H., Rosenthal, D., Kety, S. S., Schulsinger, F. \& Welner, J. (1974). Crossfostering. A research strategy for clarifying the role of genetic and experimental factors in the etiology of schizophrenia. Archives of General Psychiatry 30, 121-128.

World Health Organization Bulletin (1975). Nomenclature for factors of the HLA system; 52, 261-265. 